\title{
3. CORK: A HYDROLOGIC SEAL AND DOWNHOLE OBSERVATORY FOR DEEP-OCEAN BOREHOLES ${ }^{1}$
}

\author{
E. E. Davis, ${ }^{2}$ K. Becker,${ }^{3}$ T. Pettigrew, ${ }^{4}$ B. Carson, ${ }^{5}$ and R. MacDonald ${ }^{2}$
}

\begin{abstract}
A new tool has been developed and successfully deployed that provides a means by which cased reentry holes drilled by the Ocean Drilling Program can be hydrologically sealed and instrumented. The seal prevents flow of water into or out of a hole that would otherwise cause severe thermal and chemical disturbance to the formation drilled. The seal is capable of withstanding both positive and negative differential pressures that may be present in hydrothermally or tectonically active environments, and can be removed for later drilling operations. The instrumentation, developed for initial deployments during Ocean Drilling Program Leg 139, was designed to monitor the formation temperatures and pressures for up to 2 years during and following the recovery from drilling disturbances. A recording gauge measures absolute pressure in the borehole below the seal. A sensor string containing 10 thermistors and a fluid-sampling tube hang in the hole below the recording package. The sampling tube extends through the seal to a port, allowing the differential pressure to be measured and fluids to be tapped from deep within the hole. Data recovery and fluid sampling can be done via submersible or remotely operated vehicle.

Two units were deployed in the sediment-filled Middle Valley rift of the northern Juan de Fuca Ridge. The first was installed in Hole 857D, which was drilled to a total depth of 936 meters below seafloor, through $470 \mathrm{~m}$ of turbidite sediment and into a highly permeable sediment-sill complex that is inferred to be a sediment-sealed hydrothermal "reservoir." The second was deployed in Hole 858G, which was drilled to a total depth of 433 meters below seafloor into a buried volcanic edifice that underlies a hydrothermal vent field. Data were recovered successfully from both holes about three weeks after deployment. Temperatures and pressures recorded in Hole 858G show that formation conditions are severely affected by drilling and by downward fluid flow into the formation through a nearby uncased exploratory hole that was not adequately sealed with cement. The differential pressure across the seal in Hole $858 \mathrm{G}$ was initially $-0.24 \mathrm{MPa}$, and at the time of the data recovery was becoming increasingly negative. Temperatures and pressures recorded in Hole 857D appear to be recovering slowly from drilling disturbances. Initially, the differential pressure across the seal in this hole was $-1.10 \mathrm{MPa}$; at the time of the data recovery, the differential had reduced to $-0.55 \mathrm{MPa}$. The instruments will continue to monitor formation pressures and temperatures once per hour for 2 years.
\end{abstract}

\section{INTRODUCTION}

\section{Background}

Logging and downhole measurements have proven very successful in utilizing Deep Sea Drilling Project (DSDP) and Ocean Drilling Program (ODP) boreholes as short-term natural deep-sea laboratories while the drillship remains on site (e.g., Worthington et al., 1989). Significant progress also has been made toward developing instrumentation that would allow oceanic boreholes to be used as "natural laboratories" for long-term "observatory" experiments. Examples include medium-term deployments of seismometers during DSDP Legs 88 and 91 (Duennebier, Stephen, Gettrust, et al., 1987; Menard, Natland, Jordan, et al., 1987) and ODP Leg 128 (Ingle, Suyehiro, von Breymann, et al., 1990), and temperature monitoring experiments conducted in the Arctic offshore (Judge et al., 1989; Taylor et al., 1989) and attempted with downhole instrumentation during ODPLeg 131 (Kinoshita et al., unpubl. data, 1991).

The instrumentation described here represents a further advance towards a true "observatory" capability, with which thermal and hydrologic conditions in drilled formations can be monitored for long periods of time. At the current stage of development, this instrumen-

\footnotetext{
${ }^{\prime}$ Davis, E. E., Mottl, M. J., Fisher, A. T., et al., 1992. Proc. ODP, Init. Repts., 139: College Station, TX (Ocean Drilling Program).

${ }^{2}$ Pacific Geoscience Centre, Geological Survey of Canada, P.O. Box 6000, Sidney, B. C. V8L 4B2, Canada.

${ }^{3}$ Rosenstiel School of Marine and Atmospheric Science, University of Miami, 4600 Rickenbacker Causeway, Miami, FL 33149, U.S.A.

${ }^{4}$ Ocean Drilling Program, Texas A\&M University, 1000 Discovery Drive, College Station, TX 77840, U.S.A.

${ }^{5}$ Department of Geological Sciences, Lehigh University, Bethlehem, PA 18015 U.S.A.
}

tation includes (1) a hydrologic seal that is compatible with existing ODP reentry cones and slightly modified ODP casing hangers, (2) a data logger having sufficient power for two years of monitoring, (3) a downhole string of 10 thermistors, (4) a pressure sensor situated below the reentry cone seal, and (5) a means by which fluids can pass from the formation, through the seal, and be sampled by a submersible or a remotely operated vehicle ( $\mathrm{ROV})$. The data from the instrument can be recovered via an electrical connection that can be mated by submersible, ROV, or wireline. The seal comprises two parts. The outer part must be deployed and recovered by the drillship; the inner part, which includes the data logger and its pressure case, can be recovered by the drill ship or by an ROV.

\section{Scientific Objectives}

Fluid circulation within the sedimentary and volcanic layers of the oceanic crust and through the seafloor has been recognized to be important in many environments, including passive continental margins, accretionary prisms, mid-ocean ridges, and ridge flanks. Some quantitative constraints can be placed on the distribution and rates of flow through the seafloor by direct observation (e.g., Carson et al., 1990; Converse et al., 1984; Little et al., 1987; Macdonald et al., 1980; Schultz et al., in press) and by measurements made remotely or on cored material (e.g. Schultheiss and McPhail, 1986; Langseth et al., 1988; Davis et al., 1991, in press). One of the best ways of constraining the physical and chemical nature of crustal fluid flux, particularly at depth, is by downhole measurements and sampling. Numerous DSDP and ODP holes have penetrated permeable parts of the crust where natural fluxes are large. Unfortunately, because of the differential pressures between the warm, low-density formation fluid and the cold, higher density drilling fluid in these boreholes, and in some cases because of true subhydrostatic formation conditions, downward flow is often stimulated. The primary goal of the instrument develop- 
ment described here is to control such flow, and to monitor true in-situ conditions after drilling disturbances have decayed.

\section{Holes in Igneous Crust}

The most intense and obvious fluid and chemical fluxes through the seafloor occur at mid-ocean ridges and young ridge flanks. Unfortunately, few constraints are available from seafloor measurements on the hydrologic conditions that control fluid flow in young crust, and on the physical and chemical conditions that control the fluid-rock interactions within the crust. Models for hydrothermal systems in the oceanic crust rely on observational constraints such as temperature, pressure, and permeability. Temperatures at depth can be estimated in sedimented areas using seafloor heat flow measurements. Where advective heat transport is significant or dominates, however, such estimates are not valid, and where sediment is not present, heat flow measurements cannot be made. Formation pressures and permeabilities can only be inferred or estimated.

Drilling provides the only direct way to make these observations. Unfortunately, the nature of active hydrothermal systems prevent standard downhole sampling and logging strategies from being totally successful. In many cases where permeable parts of young oceanic crust have been penetrated, the formations have been found to be underpressured (Anderson and Zoback, 1982), at least with respect to the hydrostatic conditions that are produced within the holes that are cooled by circulation during drilling. Downhole fluid flow is stimulated, and in those cases where holes have been later reentered, this stimulated flow has been found to be relatively stable and long lived (e.g., Hyndman et al., 1976; Becker et al., 1983, 1984, 1989; Gable et al., in press; Morin et al., in press). This causes serious formation contamination problems and severely limits the quality of many downhole measurements and samples, both over short and long periods of time. The experiment outlined here provides a means by which (1) such flow can be stopped to minimize the thermal and chemical effects on the formation by the drilling-induced disturbance, and (2) the in-situ thermal and hydrological conditions can be monitored and fluids can be sampled long after holes are drilled, when the drilling disturbance will have dissipated.

Sedimented ridges and ridge flanks provide a particularly ideal environment for hydrologic borehole-seal experiments. Seafloor sediment, and in particular the clay-rich glacially derived sediment covering the northern Juan de Fuca Ridge and flank, may be several orders of magnitude less permeable than the rock of the upper igneous crust that lies beneath. Thus, cased boreholes through the sediment section can provide simple hydrologic connections to permeable formation below, and make possible the determination of local absolute pressures and lateral pressure differentials. Coupled with estimates and determinations of the regional and local thermal, tectonic, and hydrologic structure of the sediment and upper igneous crust, the flow regime in these ridge and ridge flank environments can be estimated with new confidence.

\section{Holes in Accretionary Prisms}

Fluid flow and pressure are known to be important in affecting the thermal, chemical, and deformational regime in active accretionary prisms. Locally high fluid pressures are inferred to be produced when sections of normally consolidated sediments are tectonically thickened and dewatered during accretion (e.g. Moore et al., 1990; Bangs et al., 1990). If strain rates are sufficiently high and effective permeability is low, pressures approaching lithostatic may be generated which can dramatically alter the mechanical behavior of the sediment (Davis et al., 1983). Such conditions may be transient (Fisher and Hounslow, 1990) and perhaps related to seismic or aseismic deformational events. The lateral and vertical pressure gradients that are established cause fluids to be expelled locally or diffusely from the thickening section (Moore et al., 1988; Davis et al., 1990; Shipley et al., 1990). The rates and total volumes of fluid flow are not as great as those in axial hydrothermal systems, although thermal and particularly chemical fluxes can be locally significant (Gieskes et al., 1990; Davis et al., 1990; Langseth et al., 1990; Foucher et al., 1990), and the integrated effect of the flux of expelled fluids on the diagenesis and alteration of the sediment section is suspected to be large (Kulm and Suess, 1990; Hyndman and Davis, in press).

As is the case for hydrothermal fluid flow systems, direct observational constraints on the hydrologic regime of accretionary prisms are few. Again, boreholes can provide hydraulic connections between the seafloor and hydrologically active parts of the geologic sections penetrated, and instrumented seals can provide the means by which hydrologic and thermal conditions can be monitored for long periods of time, thus allowing drilling disturbances to decay, steady-state conditions to be determined, and transient events to be observed.

\section{TECHNICAL DESCRIPTION}

\section{Requirements}

In the initial phase of design and development of the ODP reentry cone seal, it was intended to keep the mechanical assembly and the instrumentation as simple and reliable as possible. To address the problems outlined above, the design needed to include:

1. A seal inside a slightly modified ODP casing string that would prevent flow of seawater or formation fluid into or out of the borehole. All components of the seal needed to be capable of withstanding either positive or negative differential pressures of magnitudes up to the local difference between lithostatic and hydrostatic pressure. This differential could be up to several $\mathrm{MPa}$ (several hundred pounds per square inch [psi]).

2. A means to measure temperatures at points spaced down the hole. The high temperatures in hydrothermal environments must be accommodated by the sensor string.

3. A means to measure and record the fluid pressure in the formation below the seal. High stability, high sensitivity, and high dynamic range are all required, as small signals may be superimposed on large (potentially lithostatic) absolute pressures, and natural changes could take place over long periods of time.

4. A valved port through which controlled "production" tests could be conducted, during which pressure and flow rate could be monitored.

5. A means to sample borehole fluids from below the seal and casing through a section of tubing integrated with the temperaturesensor string.

\section{Design Summary}

The seal assembly, shown schematically in Figure 1, comprises three coaxial components. The outermost component is a reentry cone and casing string that is deployed in the usual manner (see "Explanatory Notes" chapter, this volume), but with particular attention paid to the quality of the grouting between the 11-3/4-in. casing and the formation in order to prevent leakage between the formation below the casing string and the seafloor. For deployments on Leg 139, the 11-3/4-in. casing string hangs in a section of 16-in. casing washed a few tens of meters into the unconsolidated part of the sediment section. No seal was made between the two casing strings. The 11-3/4-in. casing terminates in mechanically competent formation (lithified sediment and basalt); hydrologic communication between the deeper permeable rock and the cased part of the hole is dependent upon the stability of the open, uncased part of the hole. Hole collapse can lead to failure of the experiment; thus, for deployments in accretionary prisms or other environments where the part of the formation of hydrologic interest is potentially unstable, a section of perforated casing will be required.

The upper part of the standard casing hanger assembly is modified slightly to provide a landing shoulder and latching mechanism for the second component, an intermediate data-logger landing collar, re- 


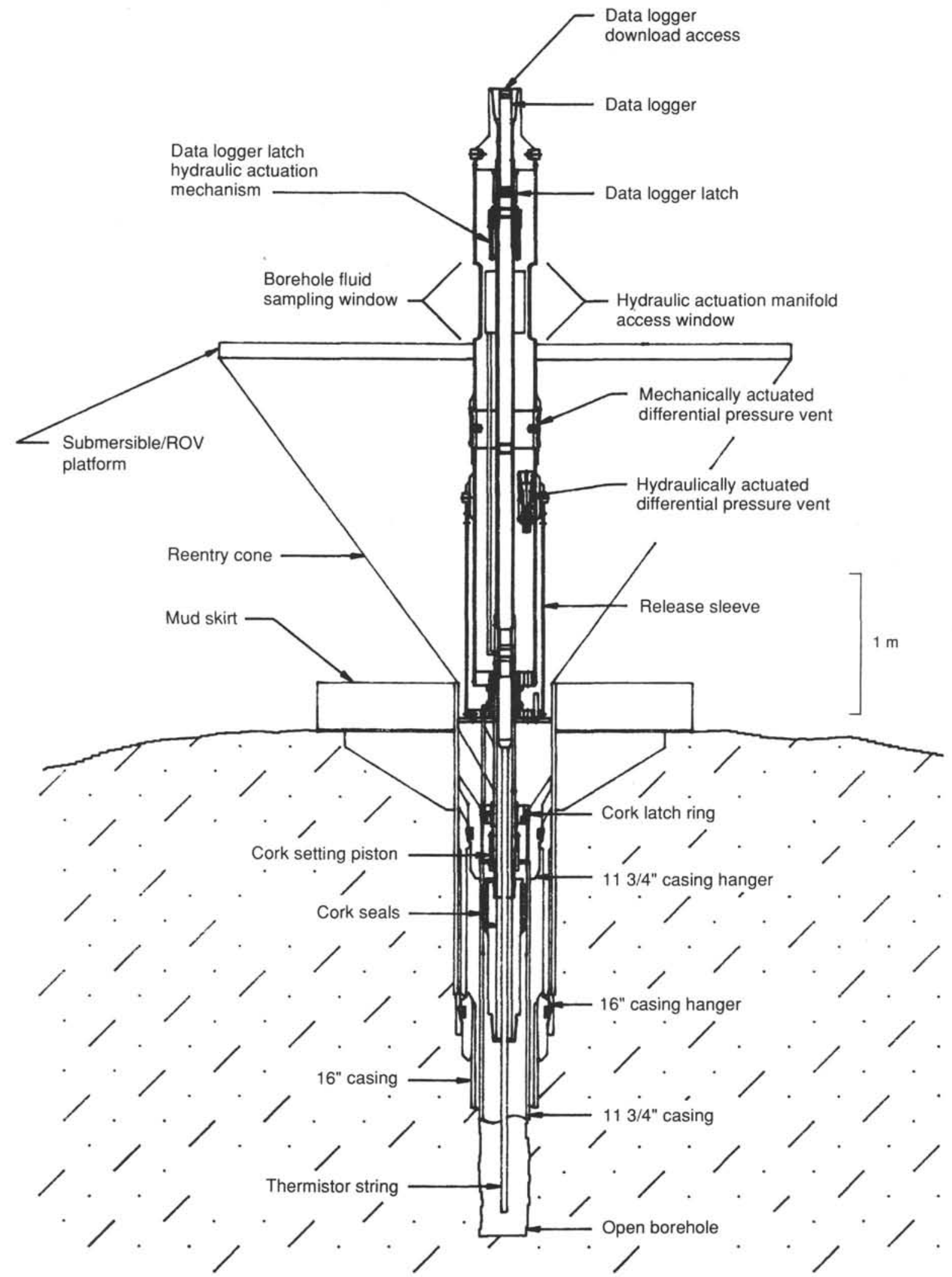

Figure 1. Schematic view of the instrumented borehole seal assembly, including the reentry cone and casing, the CORK outer seal, and the data logger inner seal. 
ferred to as the "CORK" (circulation obviation retrofit kit). The CORK provides an intermediate seal between the 11-3/4-in. casing and the third and innermost component, the data logging unit. It also contains the plumbing necessary to pass fluids around the seal, from inside to outside the borehole.

The data logging unit is contained within a multifunction pressure case which, once latched into the landing collar, provides the final innermost seal. Any instrumentation can be deployed in this configuration, as long as the outside diameter matches that of the logger pressure case, which is $90 \mathrm{~mm}$ (3.5 in.). Length is limited only by deployment constraints.

The pressure case is constructed of 4130 alloy mild steel, which matches the composition of the logger landing collar, and therefore minimizes corrosion. The surface of the upper end cap on which a face O-ring seats is plated for surface corrosion protection. A gold/tinindium surface was applied to the instruments used for the Leg 139 and was not fully satisfactory. Later instruments will be plated with copper and hard chrome. The end caps of the pressure case are mated with double piston O-ring seals that are deeply recessed and well protected by grease.

The logging unit provides analog to digital conversion and recording of up to 16 channels of voltage and resistance at any interval greater than $10 \mathrm{~s}$. Data are stored in solid-state memory having a capacity for over 26,000 sets of readings of 16 input channels. If fewer channels are recorded there is a corresponding increase in the number of sample sets that may be stored. In the experiment started on Leg 139,15 channels were utilized: date and time, borehole pressure, internal temperature, resistances of the 10 thermistors of the thermistor string, and two fixed, low temperature-coefficient resistors. Thermistor resistances are stored as 12-bit words, and pressure as 24-bit words. Power is provided by four lithium thionyl chloride "C" cells. These run the instrument for up to 2 years under typical operating conditions, and provide an additional year of data retention in a quiescent mode. Additional backup power for memory is provided by a separate lithium cell. Data retrieval and programming commands are performed over a 9600 -baud three-wire RS-232 link. The instrument hardware is mounted on an aluminum chassis within the $50 \mathrm{~mm}$ ( 2.5 in.) inside-diameter pressure case. Padded bulkheads and soft mounts at the top and bottom of the chassis provide radial and longitudinal shock absorption.

The external data communication link to the logging unit is provided by a 4-contact (only three are used), co-axial underwatermateable connector that is mounted on the top of the data logger (Ocean Design Inc. "O.D. Blue"). The top of the connector is situated just below the protective face of the top of the logger landing collar. Electrical connection can be made by submersible or remotely operated vehicle employing a simple gravity-driven, self-centering "tophat" that requires only a modest degree of dexterity to mate (Fig. 2).

A compensated, oil-filled boot directly below the logger unit, protected inside a cylindrical thermistor-string termination housing, provides corrosion protection for and houses the bulkhead connector on the end of the data logger pressure case, the connectors that mate to the thermistor leads, and the pressure transducer which is enclosed in stainless steel. A Paroscientific temperature-compensated quartz pressure transducer was used (Model 8B 4000-2), with a total range of $40-\mathrm{MPa}(4000$ meters below sea level, or mbsl $)$ and $4-\mathrm{kPa}\left(10^{-4} \times\right.$ full scale) resolution.

The combination thermistor string and fluid-sampling tube hangs below the termination housing, held taut for deployment by a $100-\mathrm{kg}$ sinker bar. The sensor string components are described in Table 1 . Each thermistor cable is an integral unit containing 10 thermistors equally spaced along its length. The tubing for fluid sampling is attached to the cable during deployment. The bottom of the tube is positioned at the desired fluid-sampling depth. The diameter of the tubing was chosen as a balance between the need to minimize the volume of fluid required to "flush" the tube before formation fluids

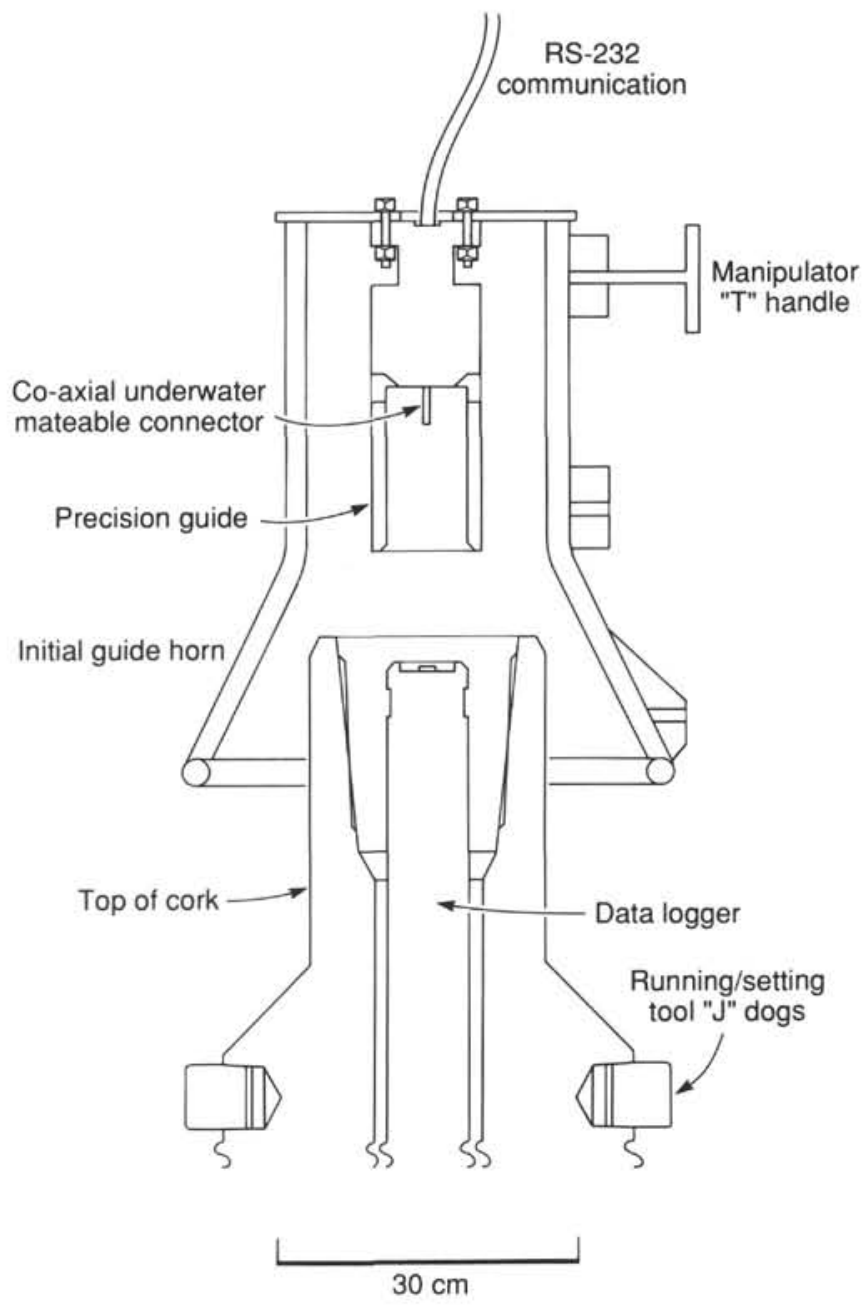

Figure 2. Schematic view of the self-centering connector that permits data to be retrieved from the borehole seal data logger.

arrive at the seafloor and the need to keep the pressure losses (resistance to flow up the tube) low.

Special sensors and component materials were required for the high temperatures and chemically hostile conditions expected during Leg 139 that precluded field modifications. Therefore, an assortment of custom cables was fabricated before the leg, of lengths and materials appropriate for the anticipated hole depths and temperatures. For deployment in the hottest holes, three PFA Teflon-insulated cables were fabricated in lengths of 100,150 , and $400 \mathrm{~m}$; for slightly lower temperatures, a single 300-m-long FEP Teflon-insulated cable was constructed. The thermistors used for all of these cables were aged by the manufacturer for 3 months at $300^{\circ} \mathrm{C}$ to develop a specified long-term stability at $300^{\circ} \mathrm{C}$ of $<1 \%$ drift per year. The thermistors were encapsulated in epoxy within teflon cylinders, and incorporated with the cable before the outer protective braid was woven on.

At the recording package, the Teflon fluid-sampling tube is connected to a titanium pipe that leads into an isolated annular cavity between the pressure case and landing collar. This fluid circuit then passes through titanium plumbing within the landing collar to a manifold at the top of the assembly, where a connection can be made for fluid sampling, external pressure measurement, and venting.

Installation of a borehole seal requires that a specially modified 11-3/4-in. casing hanger be placed in the reentry cone. All full-size ODP reentry cones deployed after Leg 135 will have the required 
Table 1. Description of the downhole sensor strings for the instrumented borehole seals deployed during Leg 139.

\begin{tabular}{|c|c|}
\hline \multicolumn{2}{|l|}{ Cables (Cortland Cable Co.) } \\
\hline Outer diameter & $2 \mathrm{~cm}$ \\
\hline Central strength member & Uniaxial Kevlar rope \\
\hline Outer protective braid & Kevlar weave \\
\hline Sensors & 10 thermistors \\
\hline Conductors & 10 independent pairs \\
\hline \multirow[t]{2}{*}{ Insulation } & FEP Teflon, $200^{\circ} \mathrm{C}$ (Hole $857 \mathrm{D}$ ) \\
\hline & PFA Teflon, $260^{\circ} \mathrm{C}$ (Hole $858 \mathrm{G}$ ) \\
\hline \multirow[t]{2}{*}{ Lengths } & $300 \mathrm{~m}$ (Hole 857D) \\
\hline & $385 \mathrm{~m}$ (Hole $858 \mathrm{G}$ ) \\
\hline \multicolumn{2}{|c|}{ Thermistors (Thermometrics, Inc.) } \\
\hline Type & SP100 \\
\hline \multirow[t]{2}{*}{ Nominal resistance } & $680 \mathrm{k}$-ohm at $25^{\circ} \mathrm{C}$ \\
\hline & $800 \mathrm{ohm}$ at $250^{\circ} \mathrm{C}$ \\
\hline Stability & $<1 \% / y r$ at $300^{\circ} \mathrm{C}$ \\
\hline \multicolumn{2}{|l|}{ Fluid sampling tubing } \\
\hline \multirow[t]{2}{*}{ Material } & FEP Teflon, $200^{\circ} \mathrm{C}$ (Hole 857D) \\
\hline & PFA Teflon, $260^{\circ} \mathrm{C}$ (Hole $858 \mathrm{G}$ ) \\
\hline Diameter & $11 \mathrm{~mm}(7 / 16 \mathrm{in}$.$) inner diameter$ \\
\hline Wall thickness & $0.8 \mathrm{~mm}(1 / 32$ in. $)$ \\
\hline \multirow{2}{*}{ Length } & $300 \mathrm{~m}$ (Hole 857D) \\
\hline & $385 \mathrm{~m}$ (Hole 858G) \\
\hline \multicolumn{2}{|l|}{ Sinker bars } \\
\hline Material & Inconel 625 (Holes 857D and 858G) \\
\hline
\end{tabular}

modified casing hanger and thus will be candidates for borehole seal installations. A CORK installation blocks wireline reentry operations until the seal is removed. Removal of the logger landing collar requires the JOIDES Resolution or a similar type of drillship. $\mathrm{Re}-$ moval and/or replacement of the thermistor string/data logger can be accomplished without the drillship, however.

\section{OPERATIONS}

\section{Deployment}

Two drill collars, referred to as the stinger (not shown in Fig. 1), are attached to the bottom of the logger landing collar prior to deployment. The stinger is used to keep the CORK centered in the reentry cone during deployment of the thermistor string/data logger. A special running tool, which "jays" or latches onto the CORK, is attached to the end of the drill string. Once the running tool has been "jayed" onto the CORK, a hydraulic latch-setting hose is made up between the running tool and the CORK (the function of this coupling is discussed below).

The CORK is then lowered to the seafloor on the drill string. Once the reentry cone is located, the CORK is positioned with the stinger in the cone throat such that the CORK cannot land or latch in the cone as the ship heaves. Since the coring wire winch used to deploy the thermistor string/data logger is not heave compensated, the drill string must be held in this position while the thermistor string/data logger assembly is deployed.

The thermistor string and fluid-sampling tube is then attached to the data logger and the assembly is lowered down the drill string on the coring wire. The sinker bar and thermistor string passes through the CORK, the stinger, and into the open borehole below. The data logger is then seated and latched inside the CORK, thus completing the first stage of the borehole seal assembly. After the data logger latch-in is confirmed, the coring wireline is shear-released and retrieved.

In the second stage of the seal assembly, heave compensation is reactivated, and the drill string is lowered until the CORK and logger subassembly lands on the 11-3/4-in. casing hanger within the reentry cone. A 4-in.-diameter plastic ball is then pumped down the drill string to land in the running tool. This allows the drill string to become pressurized. The pressure is channeled to a latch-setting piston via the hydraulic setting hose. When activated, the setting piston drives a latch ring into mating grooves in the 11-3/4-in. casing hanger. The CORK must be latched in place to prevent it from being pumpedout of the reentry coneshould apositive pressure differential be present in the borehole.

After verifying that the CORK is latched in, a submersible/ROV platform is deployed. This consists of a central sleeve and a horizontal grid of 3/4-in. bars spaced 12 in. apart that covers the reentry cone and allows a vehicle to rest stably beside the seal assembly. The two halves of the platform are positioned around the drill string and bolted together. Using the drill string as a guide, the platform is free-fall deployed. The platform automatically centers itself over the CORK as it lands on the reentry cone rim.

Once it is verified by TV inspection that the submersible/ROV platform is properly in place, the running tool is "un-jayed" from the CORK by lifting and rotating the drill string clockwise. As the running tool is removed from the CORK, the hydraulic setting hose automatically disconnects inside the CORK body. The drill string is then recovered and the instrumented borehole seal installation is complete. Each of the two deployments done in this manner on Leg 139 were completed in less than $24 \mathrm{hr}$, including the 2500 -m drill-pipe round trip.

\section{Submersible/ROV Operations}

After landing on the platform, a submersible or ROV can make a connection with the data logger and download the memory to a computer on board, and also a connection with the hydraulic feedthrough via a window on the side of the CORK. Once this latter connection is made, a valve is opened, creating a flow path from the borehole to the submersible/ROV. After the differential pressure between the borehole and the water column is measured and, if possible, a borehole fluid sample is recovered, closing the valve once again isolates the borehole.

The CORK has two internal, hydraulically controlled systems, a differential pressure vent, and the data logger latch. By using hydraulic power supplied by a submersible/ROV the thermistor string/data logger can be removed and replaced without the drillship. First, a wireline must be connected to the data logger. The differential pressure vent and the data logger latch are hydraulically opened in sequence, and then the data logger/thermistor string is removed using the attached wireline. The logger latch can also be disengaged mechanically, thus permitting removal of the logger by the drillship or by wireline only. Replacement of the data logger or other instrumentation can be accomplished by reversing the unlatching sequence.

\section{CORK Recovery}

The main body of the CORK can be recovered only by a drillship with a special pulling tool attached to the end of the drill string. After the reentry cone is located, the pulling tool is lowered over the CORK. This automatically opens the mechanically activated differential pressure vent and "jays" the pulling tool onto the CORK release sleeve. Lifting the drill string engages the CORK release sleeve, which first shifts upwards approximately 3 in. and releases the CORK latch ring. The release sleeve then engages the CORK itself, which is free to be pulled out of the reentry cone.

The CORK, along with the submersible/ROV platform, is then picked up until it is sufficiently clear of the reentry cone to prevent heave from re-seating it. At this point, only the stinger (the two drill collars attached below the CORK) is positioned in the reentry cone throat, and heave compensation can be deactivated. The coring wireline is then lowered down the drill string to retrieve the thermistor string/data logger with a mechanical latch release as described above. Once the thermistor string/data logger assembly has been removed, the CORK and submersible/ROV platform are recovered with the drill string, leaving the borehole fully open for future operations. 


\section{DEPLOYMENTS IN MIDDLE VALLEY DURING LEG 139}

\section{Geologic Environment}

Middle Valley is a seafloor spreading rift at the northern end of the Juan de Fuca Ridge, where up to $2 \mathrm{~km}$ of relatively impermeable turbidite sediments continuously blanket what is inferred to be more permeable igneous upper crust (Fig. 3). Holes were drilled at four sites to investigate four distinct parts of the submarine hydrothermal system active in the valley (see individual site chapters, this volume, for detailed descriptions). Holes at Site 855 penetrated a zone of fluid recharge along the normal-fault scarp that bounds the valley to the east. Drilling at Site 856 sampled a large polymetallic sulfide deposit created by hydrothermal fluid discharge that is no longer active. Site 857 was drilled into a hydrothermal "reservoir" zone where high-temperature fluids were suspected to reside in the upper igneous crust beneath a complete sediment seal. Holes at Site 858 were located in and immediately adjacent to a hydrothermal vent field. The holes nearest the center of the field, including the hole chosen for reentry, penetrate an active upflow zone, where hydrothermal fluids ascend through the locally attenuated section of sediment above a buried basement edifice and vent at the seafloor. CORKs were installed at the latter two of these sites, in reentry Holes 857D and 858G (Fig. 3).

Hole $857 \mathrm{D}$ penetrates through a 470 -m-thick section of turbidites and on into a sequence of interbedded sills and indurated sediments to a total depth of 936 meters below seafloor (mbsf). The hole was cased well into this sequence, down to a depth of $580 \mathrm{mbsf}$. The section in this hole below the casing includes discrete zones of extreme permeability; the combination of high permeability and the large differential pressure between the cold-hole and warm-formation hydrostats stimulated downhole flow at a rate of over $10,000 \mathrm{~L} / \mathrm{min}$ (see "Special Downhole Experiments" section, "Site 857" chapter, this volume). Sealing the hole at the seafloor was clearly necessary to prevent major thermal and chemical disturbances to the formation, and to permit in-situ temperatures and pressure to be determined.

The thermistor chain used in this hole was only $300 \mathrm{~m}$ long, less than one-third of the total hole depth, and the bottom of the
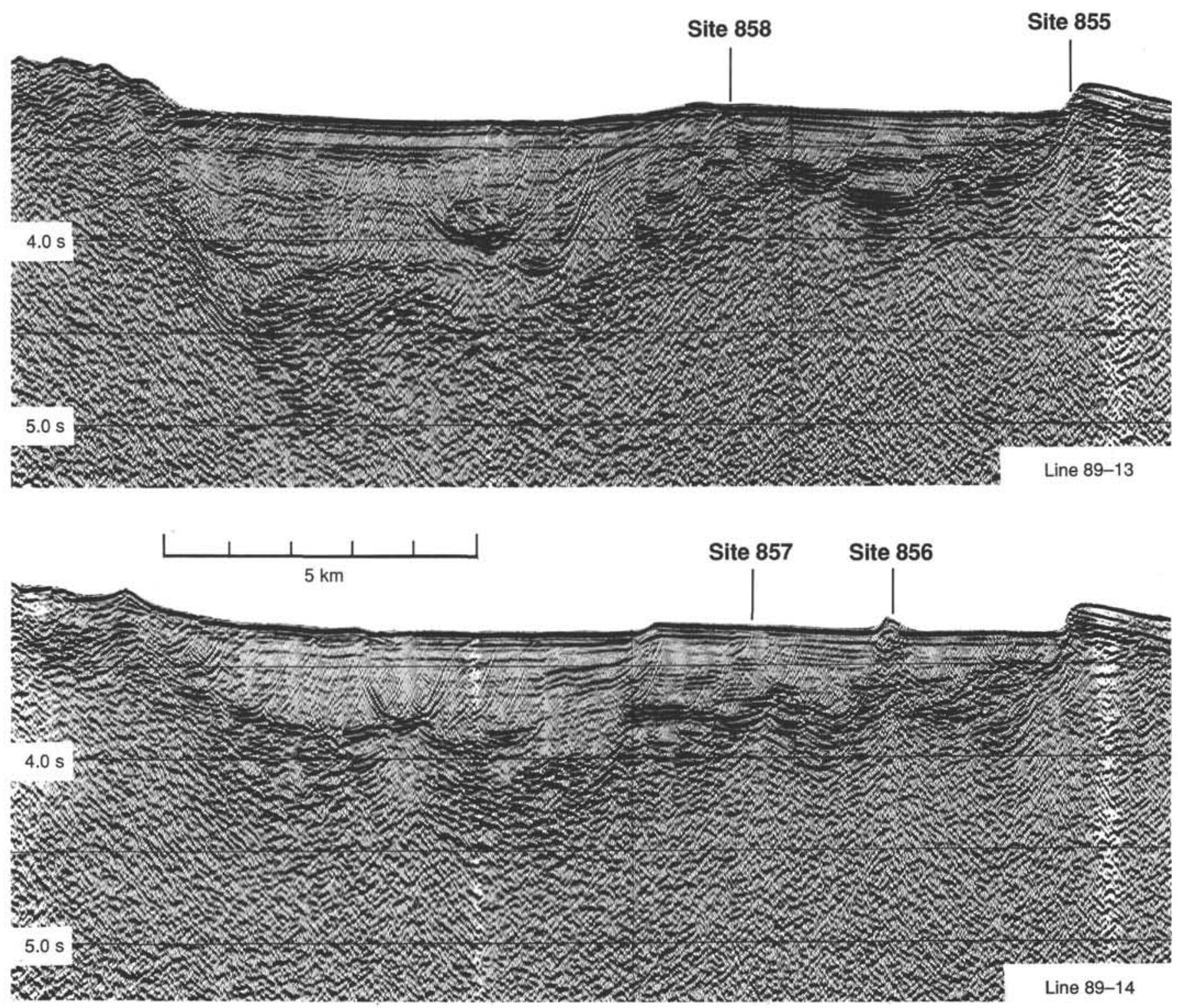

Figure 3. Seismic reflection profiles crossing Middle Valley, showing the context in which the instrumented borehole seals were installed during Leg 139. 
fluid-sampling tube was thus well above the bottom of the $580 \mathrm{~m}$ casing (Table 1; Fig. 4). The construction of thermistor chains had been guided by the anticipated depths of drilling, the thermal gradients in the area, and the temperature limits of the insulation of $270^{\circ} \mathrm{C}$. Much greater penetration was realized, and the available chains did not permit the bottoms of both reentry holes to be reached; the second longest chain of $300 \mathrm{~m}$ was used for Hole $857 \mathrm{D}$. We plan to replace the latter in the future with a 900 -m-long chain.

Hole $858 \mathrm{G}$ was drilled within the vent field to a total depth of $433 \mathrm{~m}$. Casing was set to a depth of $269 \mathrm{~m}$, about $11 \mathrm{~m}$ into basement. The basement section at this site comprises extrusive basalt, and was determined to be quite permeable, (see "Special Downhole Experiments" section, "Site 858 " chapter, this volume), although not as permeable as inferred at Site 857. Downhole fluid flow was also indicated at this site by the temperature profile measured after the hole was drilled into basement below the casing (see "Downhole Logging" section, "Site 858 " chapter, this volume). This hole was instrumented with an optimum length thermistor chain, $400 \mathrm{~m}$, the longest constructed for Leg 139 . The chain was shortened $15 \mathrm{~m}$ by doubling the lowest section, to ensure that the sinker bar did not come to rest on a ledge encountered at $395 \mathrm{~m}$ during logging. The final configuration of the instrumented hole is outlined in Table 1 and Figure 4. The chain and fluid-sampling tube reaches well below the cased section and into the open hole.

\section{Leg 139 Instrumented Borehole Seals}

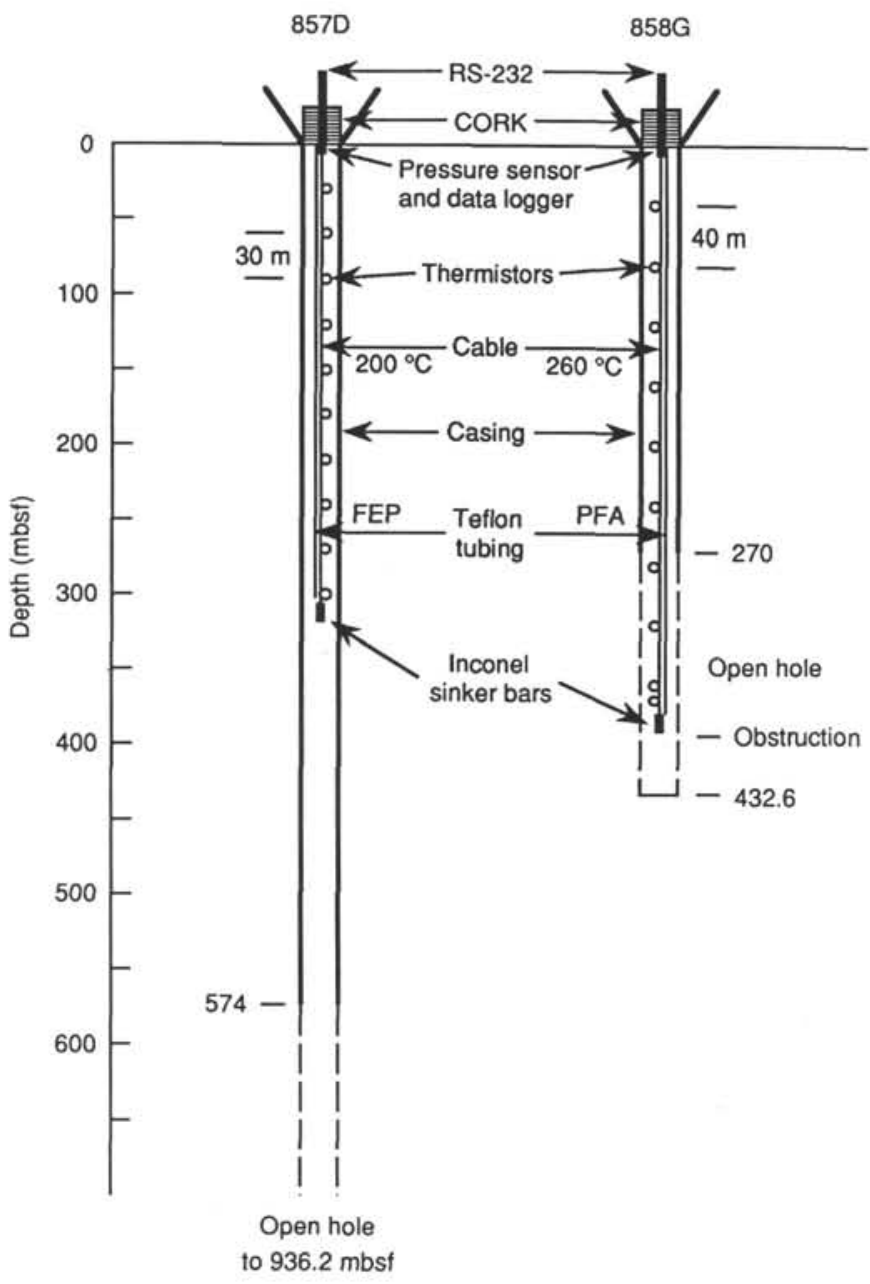

Figure 4. The configuration of the sensor strings deployed during Leg 139.

\section{Hydrologic Disturbance from Exploratory Holes}

Single-bit exploratory holes were drilled near both reentry holes to determine the depth to which 16-in. casing could be washed in, and the depth to which $11-3 / 4$-in. casing was required. Hole $857 \mathrm{C}$ is located $50 \mathrm{~m}$ to the south of Hole $857 \mathrm{D}$ and was drilled to a depth of $568 \mathrm{mbsf}$; Hole $858 \mathrm{~F}$ is located $10 \mathrm{~m}$ to the north of Hole $858 \mathrm{G}$ and was drilled to a depth of $297 \mathrm{mbsf}$. To reduce the chance that flow into or out of the formation would take place in these exploratory holes, an attempt was made to backfill both with cement. A quantity of cement was pumped that was sufficient to fill Hole 857C from an obstruction encountered during logging at 474 mbsf up to 408 mbsf. Obstructions were also encountered at 299 and 192 mbsf in this hole. Hole $858 \mathrm{~F}$ was backfilled at two levels, from 294 to $220 \mathrm{mbsf}$, and from 101 to 45 mbsf.

Unfortunately, the attempt to plug the exploratory Hole $858 \mathrm{~F}$ appears to have been unsuccessful. A temperature log in Hole 858G, completed 2 weeks after the reentry hole was established, but before it was deepened below the cased section, displayed clear evidence for fluid flow from the exploratory hole (see "Downhole Logging" section, "Site 858 " chapter, this volume). The temperature in the upper $25 \mathrm{~m}$ of the hole had recovered fully to that measured in situ during drilling, increasing from the seafloor to $268^{\circ} \mathrm{C}$ at $25 \mathrm{mbsf}$. Below this depth, however, a deep temperature inversion was observed. Measured temperatures decreased downward to $100^{\circ} \mathrm{C}$ at a depth of $60 \mathrm{~m}$, then increased toward the inferred in-situ formation temperature of about $280^{\circ} \mathrm{C}$ at the maximum depth in the casing reached by the logging tool of $160 \mathrm{mbsf}$ (an obstruction of cement stopped the temperature probe before the cement plug at the bottom of the casing was reached). This temperature inversion is believed to have resulted from the invasion of cold seawater into the sediment section below an inferred impermeable cap (an interval of hard drilling between about 25 and $50 \mathrm{mbsf}$ ) through the incompletely cemented Hole 858F.

\section{Initial CORK Results}

The schemes for data recovery and fluid sampling were tested successfully during a submersible diving program carried out with the research submersible Alvin on 24 September 1991, roughly two weeks after Leg 139 and three weeks after the installation of the CORKs ( 15.5 and 21.5 days at Holes $858 \mathrm{G}$ and $857 \mathrm{D}$, respectively). Data were recovered and fluid port connections were made at both holes during a single 7 -hr dive. Fluid samples could not be recovered from either hole because of low relative formation pressures, but differential pressures were measured successfully with an analog pressure gauge. During this initial recording period data were collected every $10 \mathrm{~min}$. Following the recovery of data, the logging interval was changed to $1 \mathrm{hr}$. Preliminary results are shown in Figures 5 and 6.

All components of the system worked well, except that the temperature records show irregularities which we are not yet able to explain fully. The thermistors appear to have suffered a shift in resistance at the time of deployment, and some of the readings display varying degrees of correlated "noise" after deployment. The cause of these problems (related to pressure, fluid leakage, cable strain, or connector strain) is currently under investigation, and will be remedied in future thermistor string constructions. To interpret the existing data, it appears that we can correct for the initial resistance offsets by calibrating the thermistor readings at appropriate times before latch-in against the known bottom-water temperature.

The preliminary data shown in Figure 5 have not been corrected for the initial resistance offset, and thus the ordinates of the plots can be considered only as approximate relative temperatures. However, two observations can be made with some confidence: temperatures in Hole $857 \mathrm{D}$ appear to be increasing with time, indicating that the hole is recovering from drilling disturbances, while temperatures in Hole $858 \mathrm{G}$ are roughly constant during the 2-week measurement 

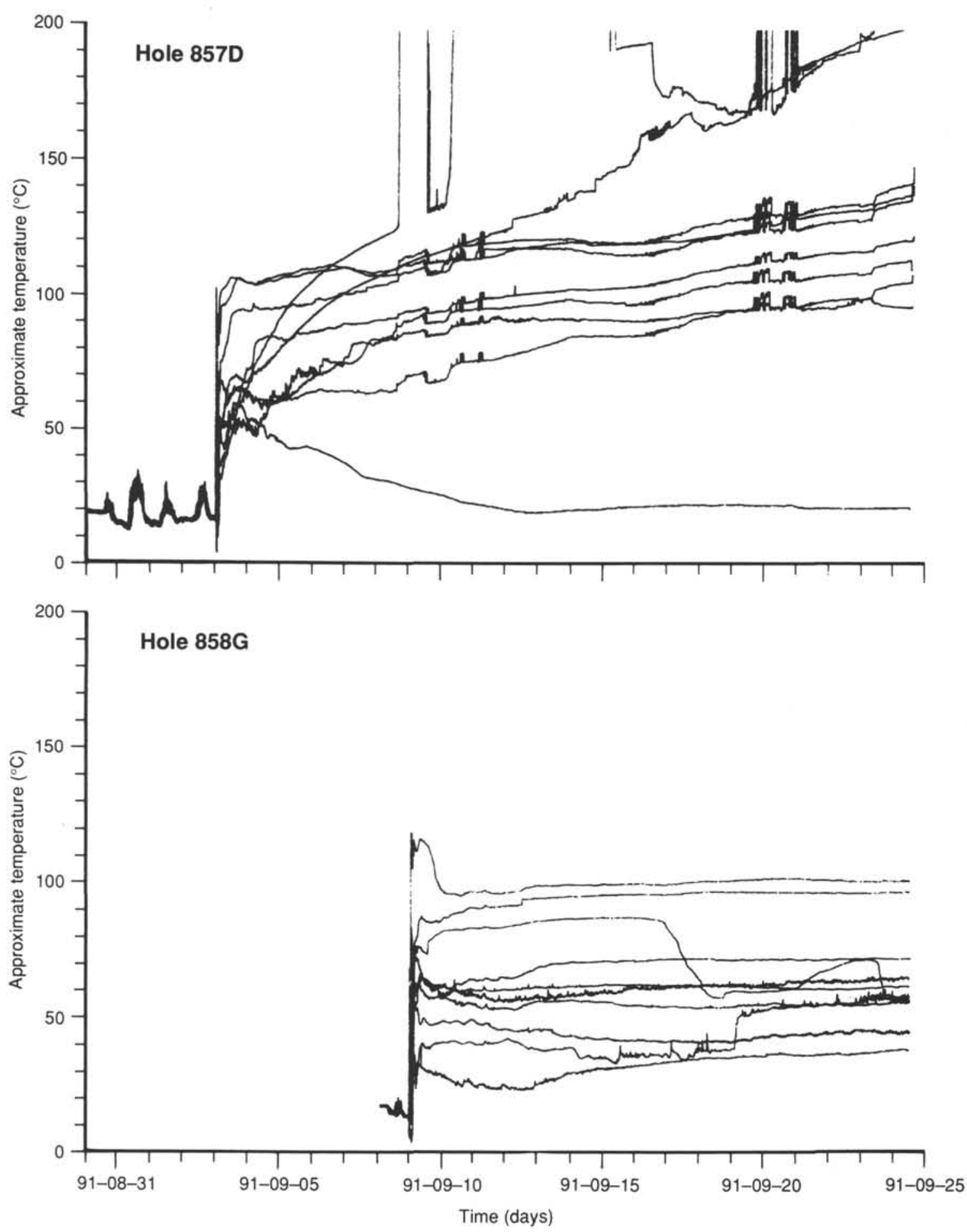

Figure 5. Preliminary data from the thermistor strings in Holes $857 \mathrm{D}$ and $858 \mathrm{G}$ from times just before deployment to the times when data were recovered with the Alvin. The conversion from resistances to temperatures is very approximate because of the presence of thermistor-to-thermistor variable offsets experienced at the time of deployment which have not been accounted for. No distinction between thermistors is made in the plot so that the reader is not drawn to premature and erroneous conclusions.

period, indicating that temperatures are still being dominated by fluid flow into the formation down the open exploratory Hole $858 \mathrm{~F}$.

These inferences are supported by the pressures in the two holes recorded during the same time period (Fig. 6). The record from Hole $857 \mathrm{D}$ displays a large negative pressure at the time of deployment $(-1.10 \mathrm{MPa}$ relative to the seafloor hydrostat), followed by a recovery towards hydrostatic conditions. At the end of the measurement period, the pressure in the formation had risen to $-0.55 \mathrm{MPa}$ below hydrostatic (determined with the analog gauge at the time of data recovery). Also evident is a diurnal oscillation that is correlated with, but damped by about $50 \%$ relative to the amplitude predicted for local tides (R. Thomson, pers. comm., 1991). 

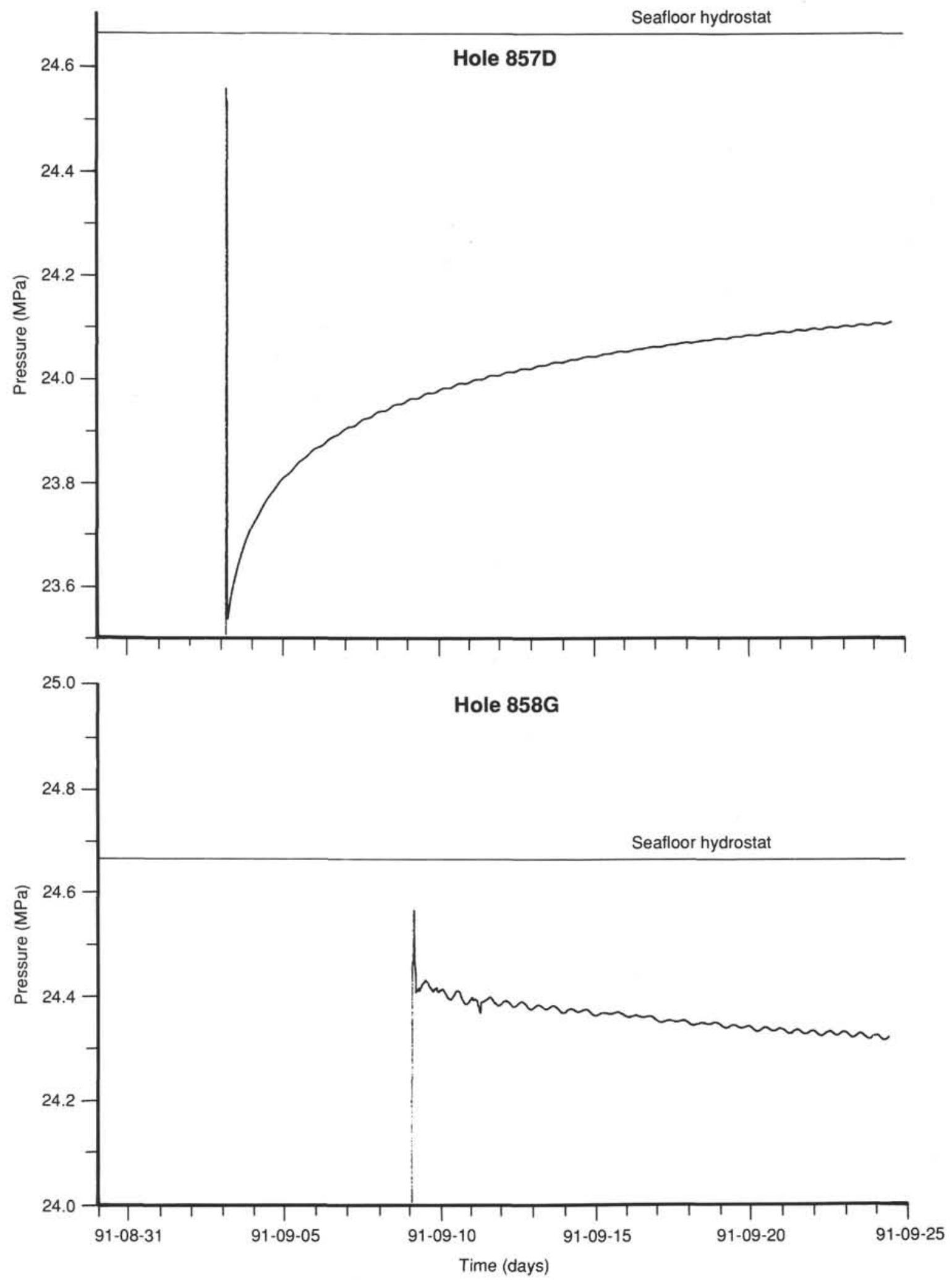

Figure 6. Preliminary pressure data from Holes $857 \mathrm{D}$ and $858 \mathrm{G}$. The local seafloor hydrostatic pressure was determined as the difference between the absolute downhole pressure and the differential measured across the seal at the time of data recovery. 
In contrast to the recovery that is underway at Hole $857 \mathrm{D}$, Hole $858 \mathrm{G}$ shows signs of continuing leakage at its neighboring exploratory hole. Firstly, the diurnal oscillations are close to the same amplitude as that predicted for local tides, indicating the presence of a hydraulic "short circuit" through the sediment section. Secondly, there is a long-term increase in the pressure differential across the seal, starting at $-0.24 \mathrm{MPa}$ at the time of deployment, and ending at $-0.35 \mathrm{MPa}$ at the time of data recovery. The increase in the negative differential is thought to be due to the increasing volume of cold water invading the formation through the open exploratory hole.

An attempt was made to seal exploratory Hole $858 \mathrm{~F}$ with a specially designed plug during an Alvin dive on 13 October 1991, following the data recovery program. This effort was successful to a limited degree only; the 2-m diameter of the plug was only marginally greater than the slightly irregular opening of the hole on the seafloor, roughly $1 \mathrm{~m}$, and the plug was not correctly centered during installation. This resulted in there being a $5-$ to $10-\mathrm{cm}$ gap between the vertical steel skirt of the plug and the seafloor along a portion of the plug's circumference. That flow was not fully stopped was confirmed when the differential pressure was measured across the plug through a valved port; no pressure drop was observed with the mechanical analog gauge (differential pressure resolution of about $10 \mathrm{kPa}$ ). Flow may have been sufficiently restricted, however, to allow the formation to begin to recover thermally and cause the driving force for the downhole flow to diminish and possibly reverse with time.

Clearly, careful consideration must be given to developing a modified strategy for drilling exploratory and reentry hole pairs in order to avoid hydrologic leakage where CORK experiments are to be performed. As a simple precaution, pairs of holes should be spaced as far apart as possible to minimize unwanted hole-to-hole hydrologic communication. Cementing may not provide a reliable means to close holes in high-permeability formations; normal cement without an aggregate is probably rapidly washed out of the hole and into the formation. Hydrofracturing may make cementing unreliable in accretionary prisms and other sedimentary formations. Special plugs that can be dropped down the drill string may be required for the exploratory holes.

\section{ACKNOWLEDGMENTS}

The instrumentation described here has become a reality through many productive discussions with various colleagues, and with the enthusiastic, generous, and talented support of the ODPEngineering and Operations Department at Texas A\&M University. T. Pettigrew provided overall engineering supervision, and designed and tested the heart of the system, the robust and ingenious CORK seal and logger landing collar. The temperature sensor strings were constructed for the University of Miami by Cortland Cable Company Inc., U.S.A., under the direction of $\mathrm{K}$. Becker. The fluid-sampling manifold and submersible hook-up was designed at Lehigh University under the direction of B. Carson. The data logger and the data recovery unit were built for the Pacific Geoscience Centre by Richard Branker and Associates, Ltd., Canada, and Inuktun Services, Ltd., Canada, respectively, under the direction of M. Bone, R. MacDonald, and E. Davis. A. Whitcombe and the pilots of the Pisces IV provided numerous helpful suggestions. Data recovery and fluid plumbing coupling was executed expertly with the Alvin by R. Grieve of Woods Hole Oceanographic Institution's Deep Submergence Group. Financial support for the project was provided by the National Science Foundation through grants to K. Becker and B. Carson (NSF OCE-9012344), by the Ocean Drilling Program, and by the Geological Survey of Canada, Department of Energy, Mines and Resources, Canada. The National Science Foundation generously supported the data recovery and subsequent hole-plugging diving programs. Thanks are also extended to R. Hyndman, R. Von Herzen, C. Forster, and A. Fisher who provided helpful comments on the manuscript. GSC contribution number 10392.

\section{REFERENCES}

Anderson, R. N., and Zoback, M. D., 1982. Permeability, underpressures, and convection in the oceanic crust near the Costa Rica Rift, eastern equatorial Pacific. J. Geophys. Res., 87:2860-2868.

Bangs, N.L.B., Westbrook, G. K., Ladd, J. W., and Buhl, P., 1990. Seismic velocities from the Barbados Ridge complex: indicators of high pore fluid pressures in an accretionary complex. J. Geophys. Res., 95:8767-8782.

Becker, K., Langseth, M. G., and Hyndman, R. D., 1984. Temperature measurements in Hole 395A, Leg 78B. In Hyndman, R. D., Salisbury, M. H., et al., Init. Repts. DSDP, 78 (Pt. 2): Washington (U.S. Govt. Printing Office), 689-698.

Becker, K., Langseth, M. G., Von Herzen, R. P., and Anderson, R. N., 1983. Deep crustal geothermal measurements, Hole 504B, Costa Rica Rift. J. Geophys. Res., 88:3447-3457.

Becker, K., Sakai, H., Adamson, A., Alexandrovich, J., Alt, J., Anderson, R., Bideau, D., Gable, R., Herzig, P., Houghton, S., Ishizuka, H., Kawahata, H., Kinoshita, H., Langseth, M., Lovell, M., Malpas, J., Masuda, H., Merrill, R., Morin, R., Mottl, M., Pariso, J., Pezard, P., Phillips, J., Sparks, J., and Uhlig, S., 1989. Drilling deep into young oceanic crust at Hole 504B, Costa Rica Rift. Rev. Geophys., 27:79-102.

Carson, B., Suess, E., and Strasser, J. C., 1990. Fluid flow and mass flux determinations at vent sites on the Cascadia margin accretionary prism. $J$. Geophys. Res., 95:8891-8898.

Converse, D. R., Holland, H. D., and Edmond, J., 1984. Flow rates in the axial hot springs of the East Pacific Rise ( $21 \mathrm{\$ N}$ ): implications for the heat budget and the formation of massive sulphide deposits. Earth Planet. Sci. Lett., 69:159-175.

Davis, D., Suppe, J., and Dahlen, F. A., 1983. Mechanics of fold-and-thrust belts and accretionary wedges. J. Geophys. Res., 88:1153-1172.

Davis, E. E., Chapman, D. S., Mottl, M. J., Bentkowski, W. J., Dadey, K., Forster, C., Nagihara, S., Rohr, K., Wheat, G., and Whiticar, M., in press. FlankFlux: An experiment to study the nature of hydrothermal circulation in young oceanic crust, Can. J. Earth Sci.

Davis, E. E., Horel, G. C., MacDonald, R. D., Villinger, H., Bennett, R. H., and $\mathrm{Li}, \mathrm{H} ., 1991$. Pore pressures and permeabilities measured in marine sediments with a tethered probe. J. Geophys. Res., 96:5975-5984.

Davis, E. E., Hyndman, R. D., and Villinger, H., 1990. Rates of fluid expulsion across the northern Cascadia accretionary prism: constraints from new heat flow and multichannel seismic reflection data. J. Geophys. Res., 95:8869-8889.

Duennebier, F. K., Stephen, R., Gettrust, J. F., et al., 1987. Init. Repts. DSDP, 88: Washington (U.S. Govt. Printing Office).

Fisher, A. T., and Hounslow, M. W., 1990. Transient fluid flow through the toe of the Barbados accretionary complex: constraints from Ocean Drilling Program Leg 110 heat flow studies and simple models. J. Geophys. Res., 95:8845-8858.

Foucher, J. P., Le Pichon, X., Lallemant, S., Hobart, M. A., Henry, P., Benedetti, M., Westbrook, G. K., and Langseth, M. G., 1990. Heat flow, tectonics, and fluid circulation at the toe of the Barbados Ridge accretionary prism. J. Geophys. Res., 95:8859-8868.

Gable, R., Morin, R., and Becker, K., in press. Geothermal state of DSDP Holes 333A, 395A and 534A: results from the Dianaut program. Geophys. Res. Lett.

Gieskes, J. M., Vrolijk, P., and Blanc, G., 1990. Hydrogeochemistry of the northern Barbados accretionary complex transect: Ocean Drilling Project Leg 110. J. Geophys. Res., 95:8809-8818.

Hyndman, R. D., and Davis, E. E., in press. A mechanism for the formation of methane hydrate and seafloor bottom simulating reflectors by vertical fluid expulsion. J. Geophys. Res.

Hyndman, R. D., Von Herzen, R. P., Erickson, A. J., and Jolivet, J., 1976. Heat flow measurements in deep crustal holes on the Mid-Atlantic Ridge. $J$. Geophys Res., 81:4053-4060.

Ingle, J. C., Jr., Suyehiro, K., von Breymann, M. T., et al., 1990. Proc. ODP, Init. Repts., 128: College Station, TX (Ocean Drilling Program).

Judge, A., Duguid, A., Taylor, A., and Allen, V., 1989. The automatic well temperature measuring system installed at Cape Allison C-47 offshore well, Arctic Islands of Canada, Part 1: concept and development. J. Can. Petrol. Tech., 28:89-94.

Kulm, L. D., and Suess, E., 1990. Relationship between carbonate deposits and fluid venting: Oregon accretionary prism. J. Geophys. Res., 95:8899-8916.

Langseth, M. G., Mottl, M. J., Hobart, M. A., and Fisher, A., 1988. The distribution of geothermal and geochemical gradients near Site 501/504: 
implications for hydrothermal circulation in the oceanic crust. In Becker, K., Sakai, H., et al., Proc. ODP, Init. Repts., 111: College Station, TX (Ocean Drilling Program), 23-32.

Langseth, M. G., Westbrook, G. K., and Hobart, M., 1990. Contrasting geothermal regimes of the Barbados Ridge accretionary complex. J. Geophys. Res. 95:8829-8844.

Little, S. A., Stolzenbach, K. D., and Von Herzen, R. P., 1987. Measurements of plume flow from a hydrothermal vent field. J. Geophys. Res., 92:2587-2596.

Macdonald, K. C., Becker, K., Spiess, F. N., and Ballard, R. D., 1980. Hydrothermal heat flux of the "black smoker" vents on the East Pacific Rise. Earth Planet. Sci. Lett., 48:1-7.

Menard, H. W., Natland, J. H., Jordan, T. H., Orcutt, J. A., et al., 1987. Init. Repts. DSDP, 91: Washington (U.S. Govt. Printing Office).

Moore, G. F., Shipley, T. H., Stoffa, P. L., Karig, D. E., Taira, A., Kuramoto, S., Tokuyama, H., and Suyehiro, K., 1990. Structure of the Nankai Trough accretionary zone from multichannel seismic reflection data. J. Geophys. Res., 95:8753-8766.

Moore, J., Mascle, A., Taylor, E., Andreieff, P., Alvarez, F., Barnes, R., Beck, C., Behrmann, J., Blanc, G., Brown, K., Clark, M., Dolan, J., Fisher, A., Gieskes, J., Hounslow, M., McLellan, P., Moran, K., Ogawa, Y., Sakai, T., Schoonmaker, J., Vrolijk, P., Wilkens, R., and Williams, C., 1988. Tectonics and hydrogeology of the northern Barbados Ridge: results from Ocean Drilling Program Leg 110. Geol. Soc. Am. Bull., 100:1578-1593.
Morin, R. H., Hess, A. E., and Becker, K., in press. In situ measurements of fluid flow in DSDP Holes 395A and 534A: results from the DIANAUT program. Geophys. Res. Lett.

Schultheiss, P. J., and McPhail, S. D., 1986. Direct indication of pore water advection from pore pressure measurements in Madeira Abyssal Plain sediments. Nature, 320:348-350.

Schultz, A., Delaney, J. R., and McDuff, R. E., in press. On the partitioning of heat flux between diffuse and point-source seafloor venting. J. Geophys. Res.

Shipley, T. H., Stoffa, P. L., and Dean, D. F., 1990. Underthrust sediments, fluid migration paths, and mud volcanoes associated with the accretionary wedge off Costa Rica: Middle America trench. J. Geophys. Res., 95:8743-8752.

Taylor, A., Judge, A., and Allen, V., 1989. The automatic well temperature measuring system installed at Cape Allison C-47 offshore well, Arctic Islands of Canada, Part 2-data retrieval and analysis of the thermal regime. J. Can. Petrol. Tech., 28:95-101.

Worthington, P. F., Anderson, R. N., Jarrard, R. D., Becker, K., Bell, J. S., Salisbury, M. H., and Stephen, R. A., 1989. Scientific applications of downhole measurements in the ocean basins. Basin Res., 1:223-236.

Ms 139A-103 